Brit. J. vener. Dis. (1966), 42, 191.

\title{
OUTBREAK OF NON-SPECIFIC URETHRITIS ASSOCIATED WITH THE PRESENCE OF COMPLEMENT-FIXING ANTIBODIES TO THE LB4 STRAIN OF TRIC AGENT*
}

\author{
BY \\ T. PASIECZNY \\ Department of Dermatology, Royal Infirmary, Glasgow, \\ AND \\ R. G. SOMMERVILLE \\ Department of Laboratory Medicine, Belvedere Hospital, Glasgow
}

The diagnosis of non-specific urethritis in the male is usually based upon the presence of a characteristic urethral discharge associated with burning on urination, and upon the absence, in stained smears, of bacterial pathogens. Careful examination may reveal typical inclusion bodies in epithelial scrapings stained by Giemsa's method and a few reports have been published describing the isolation of an agent by the inoculation of scrapings into fertile eggs (Jones, Al-Hussaini and Dunlop, 1964; Dunlop, Al-Hussaini, Garland, Treharne, Harper, and Jones, 1965). This agent has been named TRIC (trachomainclusion conjunctivitis) to acknowledge its association with these two diseases, and serological studies have demonstrated that the "TRIC agent" is actually a group of serologically related agents (Nichols and McComb, 1964).

Routine laboratory diagnosis, however, has awaited the development of satisfactory serological tests which could give an accurate, quick assessment of the condition in terms of the immune response in infected individuals. Work along these lines has been hampered by lack of specificity and often by the finding of extremely low antibody titres to group antigen in individuals from whom a TRIC agent has been isolated (Jones and others, 1964).

\section{Present Investigation}

During a 13-month period we examined serum specimens from groups of males suffering from urethritis by a complement-fixation test using a simple TRIC agent antigen prepared from the LB4 strain and found raised antibody titres in a high proportion.

* Received for publication December 2, 1965
In this paper we wish to describe what we now believe was a circumscribed outbreak of TRIC urethritis, comparing the clinical features with the serological results obtained.

\section{Material and Methods}

(a) Clinical.-The investigation covered the period June, 1963, to July, 1964, and included 565 male cases presenting at the VD clinics in the city of Glasgow. The final clinical diagnosis segregated the cases into four groups:
(1) Non-specific Urethritis
(2) No Disease Found
(200 cases)
(3) Gonococcal Urethritis
(200 cases)
(4) Syphilis
(114 cases)
(51 cases)

Each new patient was carefully examined clinically and an "on the spot" check was made by Gram stain of the urethral discharge. By this technique we included in the "non-specific urethritis" group only cases having only pus cells and epithelial cells in the stained smear. When bacteria were seen the case was excluded from the group.

Irrespective of the group to which he was allocated on clinical grounds, each new patient had a blood specimen drawn for laboratory examination.

(b) Virological.-The sera were separated and stored frozen at $-20^{\circ} \mathrm{C}$. Testing was carried out on batches of 40 to 50 sera at a time and each was inactivated at $56^{\circ} \mathrm{C}$. for $30 \mathrm{~min}$. immediately before testing.

The antigen was prepared from the LB4 strain of TRIC agent, which was kindly supplied by the Lister Institute, London. This strain was grown in Roux flask monolayer cultures of HEp2 cells, maintained in Earle's saline containing 5 per cent. calf serum. Infected monolayers were maintained at $37^{\circ} \mathrm{C}$. until complete cytopathic degeneration occurred (usually between 5 and 7 days) when the entire content of the flasks was harvested.

The degenerate cells were separated by centrifugation and disintegrated by repeated freezing and thawing. The cell debris was then returned to the original supernate 
and the bulk antigen was stored in aliquots at $-40^{\circ} \mathrm{C}$. Each new aliquot was titrated in a checker-board test against homologous hyperimmune rabbit serum to determine its optimal concentration.

All sera were examined by a cold-overnight complement-fixation test (C.F.T.) using 2 units of preserved complement, and sera giving a reciprocal C.F. titre of 32 or greater were regarded as positive.

\section{Results}

The clinical particulars and laboratory results relating to each group are summarized in the Table.

\section{Discussion}

A number of significant factors emerge from a consideration of these results. The usual serological test for antibody to the TRIC agents utilizes the common group antigen, which is thought to be present in all related agents belonging to the TRIC group, and which is also present in the psittacosislymphogranuloma venereum agents. In the work described here we have made use of an apparently type-specific antigen, obtained by growing TRIC agent in tissue culture, and this is the first reported instance in which a "type-specific" test has been applied to the diagnosis of cases of non-specific urethritis.

In this type-specific test we have observed antibody levels which correspond to those usually observed in measuring antibody response to respiratory antigens. The magnitude of the antibody response may be due in part to the specific nature of the antigen used. Only experience will allow assessment of the point at which a titre falls into the positive range, and it may be that the level taken here of 32 or above has been set too high.

The widespread scatter of positive results over the four groups of persons described and the approximately equal distribution of positive cases in three of these groups points to the wide dissemination of the agent in the population at risk during the 13 months of experimental observation. Non-specific urethritis is seasonal in W. Scotland, with maximal incidence between March and October (see Figure, opposite). Screening was carried out on similar cases occurring before June, 1963, and after July, 1964, and the incidence of positive results outside this period, using the LB4 antigen, was almost zero. This fact surely indicates that during the 13-month period we were dealing with an agent which was imported into the area and which caused what almost amounted to a localized outbreak of disease which was almost certainly transmitted by sexual contact as a venereal infection.

The relatively simple nature of the condition and its rapid disappearance after treatment with oxytetracycline made follow-up extremely difficult in

TABLE

CLINICAL PARTICULARS OF THE FOUR GROUPS OF PATIENTS

\begin{tabular}{|c|c|c|c|c|c|c|}
\hline Group $\quad \ldots$ & .. & $\ldots$ & 1 & 2 & 3 & 4 \\
\hline Diagnosis & . & . & $\begin{array}{c}\text { Non-specific } \\
\text { Urethritis }\end{array}$ & Control & $\begin{array}{c}\text { Acute } \\
\text { Gonorrhoea }\end{array}$ & Syphilis \\
\hline No. of Cases & $\ldots$ & . & 200 & 200 & 114 & $51 t$ \\
\hline Age Range (yrs) & 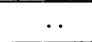 & $\ldots$ & $18-57$ & $16-90$ & $18-68$ & $18-73$ \\
\hline Occupation (per cent.) & \multicolumn{2}{|c|}{$\begin{array}{l}\text { Labourers } \\
\text { White-collar } \\
\text { Retired .. }\end{array}$} & $\begin{array}{l}59 \\
41 \\
-\end{array}$ & $\begin{array}{l}40 \\
35 \\
25\end{array}$ & $\begin{array}{l}62 \\
38 \\
-\end{array}$ & $\begin{array}{l}35 \\
30 \\
35\end{array}$ \\
\hline Marital Status & \multicolumn{2}{|c|}{$\begin{array}{l}\text { Single } \\
\text { Married* } \\
\text { Widower or } \\
\text { Separated }\end{array}$} & $\begin{array}{r}118 \\
64 \\
18\end{array}$ & $\begin{array}{r}115 \\
85 \\
-\end{array}$ & $\begin{array}{r}78 \\
32 \\
4\end{array}$ & $\begin{array}{l}22 \\
17 \\
12\end{array}$ \\
\hline \multirow{3}{*}{$\begin{array}{l}\text { LB4 Reciprocal } \\
\text { Complement-Fixation } \\
\text { Titres } . . \quad \begin{array}{lll}\text {. } & \ldots\end{array}\end{array}$} & 4-16 & $\begin{array}{c}\text { No. } \\
\text { Per cent. }\end{array}$ & $\begin{array}{r}150 \\
75\end{array}$ & $\begin{array}{c}169 \\
84.5\end{array}$ & $\begin{array}{l}89 \\
78\end{array}$ & $\begin{array}{l}48 \\
94\end{array}$ \\
\hline & Total & $\begin{array}{c}\text { No. } \\
\text { Per cent. }\end{array}$ & $\begin{array}{l}50 \\
25\end{array}$ & $\begin{array}{l}31 \\
15 \cdot 5\end{array}$ & $\begin{array}{l}25 \\
22\end{array}$ & $\begin{array}{l}3 \\
6\end{array}$ \\
\hline & $32+$ & $\begin{array}{r}32 \\
64 \\
128 \\
256\end{array}$ & $\begin{array}{r}32 \\
13 \\
1 \\
4\end{array}$ & $\begin{array}{r}22 \\
64 \\
0 \\
1\end{array}$ & $\begin{array}{r}11 \\
10 \\
3 \\
1\end{array}$ & $\begin{array}{l}2 \\
1 \\
0 \\
0\end{array}$ \\
\hline
\end{tabular}

* Extra marital intercourse admitted: 1, 49 per cent.; 2, 60 per cent.; 3, 52 per cent.; 4, Not stated.

† 35 latent, 6 primary, 8 secondary, 2 congenital 


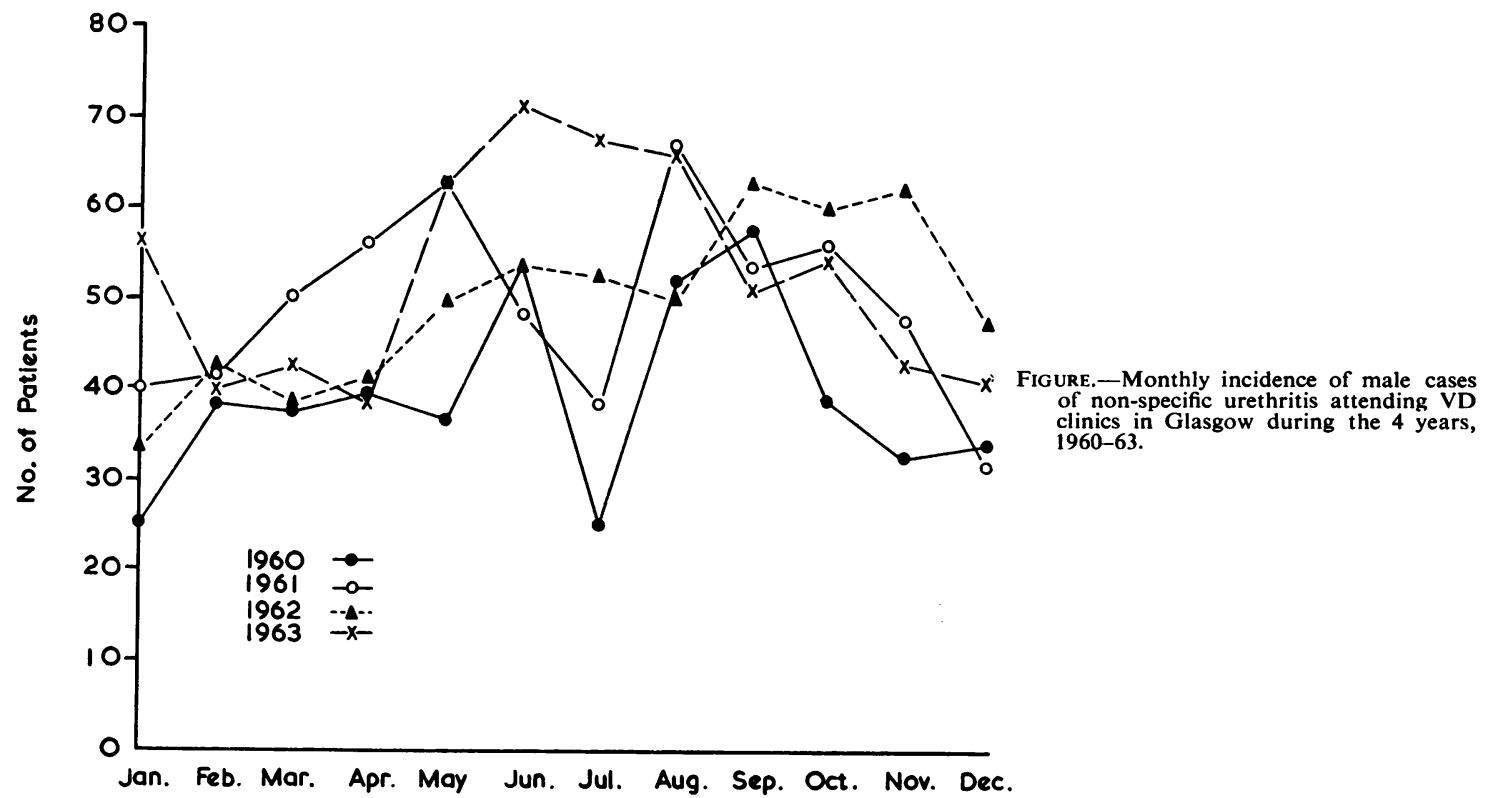

the majority of patients falling into our first and second groups. In consequence, it was almost impossible to obtain more than one blood specimen. In the third and fourth groups, however, it was possible to obtain repeat specimens in some instances, although here also a number became defaulters.

In Group 2, which we have designated as our "control" group, the simple explanation of the perhaps surprising incidence of antibody must lie in the fact that we were here dealing with a group of promiscuous people. As a consequence the sexual experience which caused them to seek advice on the occasion in question may not have been the first promiscuous sex contact, and although they could be excluded from the non-specific urethritis group in the present context, we may have been measuring residual antibody from previous and even recent infection.

In Group 3 (acute gonorrhoea), the only case with a reciprocal titre (LB4) of 256 failed to respond completely to three courses of penicillin at 300,000 , 600,000 , and mega-unit strength, but the discharge rapidly cleared with $1 \mathrm{~g}$. terramycin daily for 4 days. The LB4 antibody titres dropped from 256 to 16 within 4 weeks of the patients' becoming symptomfree. In two cases with titres of 64 , terramycin also produced a rapid cure, the antibody titre dropping after 6 weeks to 16 and 8 respectively.
In the syphilitic group, when treatment was by penicillin injection at mega-unit strength, the antibody titres to the LB4 agent fell from 64 to 16 in one individual within 3 weeks, and from 32 to 8 and 4 respectively in the other two individuals, also in 3 weeks.

Much remains to be learned about the aetiology of non-specific urethritis and the part played by TRIC agents in its causation. It is important, however, in developing our complete understanding of the condition, to realize that infection with TRIC agents can be acquired by sexual contact and that the finding of $N$. gonorrhoea, or of Treponema pallidum does not exclude the possibility of concomitant infection with an agent of the TRIC group. Indeed, it might be argued on $a$ priori grounds that the presence of a pathogenic bacterial species in the urethra may open the way more readily for invasion by an agent of the TRIC group, despite the fact that such a contention was not borne out in the series of cases reported here.

Indeed the comparative frequency in the present series of TRIC agent antibody associated with acute gonorrhoea presents strong evidence for the presence of a dual infection. In these circumstances it is reasonable to propose the use of wider-spectrum antibiotics in the treatment of gonorrhoea. The TRIC agents are not sensitive to penicillin, whereas they do respond to tetracycline with commendable speed. 


\section{Summary}

565 patients attending venereal disease clinics were classified on clinical and bacteriological evidence into four groups: non-specific urethritis, no obvious disease (control), acute gonorrhoea, and syphilis.

Serum from these persons was examined by complement-fixation test for antibody to the LB4 agent, which belongs to the TRIC group. Positive reciprocal titres of 32 or greater were found in 25 per cent. of the non-specific urethritis cases, in 15 per cent. of the controls, in 22 per cent of cases of acute gonorrhoea, and in 6 per cent. of the small series of cases of syphilis.

We are grateful to Dr Elizabeth Hart of the Lister Institute of Preventive Medicine, London, for generously providing the seed of the LB4 strain of TRIC agent used for this study, and to Mr H. G. Carson, F.I.M.L.T., for help with the complement-fixation tests.

\section{REFERENCES}

Dunlop, E. M. C., Al-Hussaini, M. K., Garland, J. A., Treharne, J. D., Harper, I. A., and Jones, B. R. (1965). Lancet, 1, 1125.

Jones, B. R., Al-Hussaini, M. K., and Dunlop, E. M. C. (1964). Brit. J. vener. Dis., 40, 19.

Nichols, R. L., and McComb, D. E. (1964). J. exp. Med., 120,639 .

Une manifestation d'urétrite non-specifique associée à la présence d'anticorps agissant comme complément de fixation à la souche LB4 de l'agent TRIC

RÉSUMÉ

565 patientes visitant les dispensaires anti-vénériens ont été classifiés selon les manifestations cliniques et bactériologiques en 4 groupes: urétrite non-spécifique, sans maladie évidente (contrôle), blennorragie aiguë, et syphilis.

Le sérum de ces personnes a été examiné par le test de complément de fixation pour anticorps à l'agent LB4, qui appartient au groupe TRIC. Des titres réciproques positives de 32 ou plus ont été trouvés dans 25 pour cent des urétrites non-spécifiques, 15 pour cent des contrôles, 22 pour cent des cas de blennorragie aiguë, et dans 6 pour cent du petit nombre de cas de syphilis. 